\title{
ANALISIS AKAD TIJARAH PADA TRANSAKSI FINTECH SYARIAH DENGAN PENDEKATAN MAQHASID
}

\author{
Dodi Yarli \\ Sekolah Tinggi Ekonomi Islam (STEI) Tazkia Bogor \\ Dodiyarli@gmail.com
}

\begin{abstract}
Financial technology is an activity that focuses on providing financial services ideas using software. Which is fintech, it expected that various facilities can be obtained later. The development of fintech began since the discovery of blockhain and cryptocurrency. In addition, this development is also one of the developments in digital-based technology and is a new innovation and his impact on all economic activities, especially in the Islamic economy.

As for Fintech Syariah, of course it must be based on an Islamic perspective and refer to Maqashid Syari'ah al-Khams and contain benefits for every transaction carried out by the contractor. All forms of economy and business transactions originating from the Qur'an and the Sunnah are clear, paying attention to and protecting the rights of each individual in order to uphold justice and eliminate injustice in transacting through the shariah fintech.

Keywords : Fintech Syariah, Maysir, Gharar, Riba, Maqashid Syari'ah al-Khams
\end{abstract}

\section{Pendahuluan}

Teknologi digital merupakan terobosan serta inovasi baru dalam seluruh kegiatan ekonomi. Hal tersebut dapat mempengaruhi sektor perdagangan, pertanian dan secara khusus pada sektor keuangan. Salah satu sektor yang saat ini dikembangkan yaitu finansial technology atau lebih dikenal dengan istilah fintech yang menjadi inovasi terbaru masa kini. Menurut (IOSCO, 2017) Teknologi Finansial adalah bisnis yang berfokus pada penyedia gagasan jasa finansial yang menggunakan perangkat lunak dan modern. Sedangkan menurut Wonglimpiyarat (2017) Fintech telah mendapat perhatian secara global sebagai teknologi menantang yang akan memberdayakan perusahaan untuk bersaing dengan efektif pada abad dua puluh satu saat ini. Pemerintah didunia saat ini telah memberikan perhatian mengenai tantangan dan merancang kebijakan serta peraturan untuk mendukung perkembangan fintech.

Pertumbuhan fintech berdasarkan data yang terdaftar di OJK (Otoritas Jasa Keuangan) sampai bulan Maret 2018 mengalami 
peningkatan yang baik, sekitar 40 perusahaan fintech syariah sudah mendapat izin resmi untuk beroperasi dari OJK.

Seiring perkembangan fintech saat ini, maka penerapannya dalam fiqh muamalah menurut perspektif Islam harus sesuai dengan prinsipprinsip syariah, yang terhindar dari Maysir, Gharar dan Riba. Selain itu, meskipun kegiatan tersebut menggunakan sistem teknologi maka prinsip-prinsip hukum ekonomi Islam harus tetap ditegakkan. Untuk itu penelitian terhadap akad akad tijarah dalam transaksi fintech dengan pendekata maqashid syariah ini harus dilakukan sehingga umat muslim dapat mengikuti perkembangan teknologi dan menggunakannya dengan tersedianya lembaga keuangan berbasis fintech yang mana dalam transaksinya sesuai dengan maqashid syariah.

Pendekatan yang dilakukan dalam analisis ini melalui pendekatan maqashid syariah dan ushul fiqh sebagai landasan utama dalam menentukan ijtihad hukum. Sehingga dapat menciptakan kesinambungan antara praktek dengan teori berdasarkan sumber yang berkaitan dengan tema yang disampaikan.

\section{Pengertian Fintech secara Umum dan Syariah}

Pengertian finansial teknologi menurut PwC (2017) fintech adalah segmen dinamis di persimpangan antara sektor jasa keuangan dengan teknologi dimana start up yang berfokus pada teknologi dan merupakan pendatang pasar baru berinovasi produk dan layanan yang saat ini disediakan oleh industri jasa keuangan tradisional. Adapun pengertian lain dari fintech mengacu pada penggunaan teknologi untuk memberikan solusi dalam sektor keuangan (Arner, 2016)

Pengertian Fintech Syariah menurut Mukhlisin (2017) adalah kombinasi, inovasi yang ada dalam bidang keuangan dan teknologi yang memudahkan proses transaksi dan investasi berdasarkan nilainilai syariah. Ia berpendapat, walaupun fintech ini merupakan terobosan baru tetapi mengalami perkembangan yang pesat. Islam merupakan agama yang komprehensif sehingga dalam bidang keuangan ini harus memiliki aturan yang sesuai dengan prinsipnya sesuai syariah.

\section{Perkembangan Fintech Syariah}

Perkembangan teknologi ditandai dengan kemunculan Finansial Technology (fintech) serta menjadi salah satu bukti perkembangan teknologi berbasis digital yang merupakan inovasi baru dan berdampak pada semua kegiatan ekonomi. Adapun fintech ini merupakan bisnis yang berfokus pada penyediaan layanan keuangan dengan menggunakan software dan teknologi modern. Selain itu, teori yang menjelaskan tentang fintech yang diperkenalkan oleh ekonom Joseph 
Schumpeter dengan teorinya yaitu creatif destruction yang mana teori ini berisi tentang pernyataan bahwa dengan adanya temuan-temuan baru yang berdampak menghancurkan pemain lama kemudian menggantikannya dengan sesuatu yang baru. Akan tetapi teori ini tidak dapat menjelaskan secara rinci mengenai dampak dari adanya terobosan baru berupa fintech. Alasannya karena kemunculan fintech bukan untuk menghancurkan incumbents yang sudah sejak lama keberadaannya. Akan tetapi, fintech mengurangi secara perlahan fungsi-fungsi incumbents dengan sesuatu yang lebih baik, lebih cepat dan lebih murah (Kasali, 2017). Selain itu, tujuan dari adanya fintech harus selaras dengan tujuan dari transaksinya untuk mendatangkan dan memelihara kemaslahatan (kebaikan) sekaligus menghindari kemafsadatan (kerusakan) baik didunia maupun diakhirat (Shidik, 2016)

Berkembangnya fintech konvensional diikuti pula dengan perkembangan fintech yang berbasis syariah. Tentu saja terdapat perbedaan antara fintech syariah dengan fintech konvensional. Karena kesesuaian transaksi yang dilakukan tentu saja harus sesuai dengan aturan syariah baik dalam rukun dan juga syarat dalam akad. Kemunculan fintech syariah sejalan dengan perubahan akan teknologi yang semakin maju sehingga gaya hidup manusia juga ikut berubah sesuai perkembangan zaman.

\section{Peer to Peer Landing}

Peer to peer landing (P2P) adalah platform pinjam meminjam secara online. Melalui platform online transparansi dan keterbukaan informasi dapat membuat akses terhadap permodalan menjadi lebih mudah dan terjangkau. Peminjam dengan keterbatasan akses bisa mendapatkan kemudahan proses dan rate yang terjangkau. Disisi lain, pendana dapat memperoleh alternatif investasi yang lebih menguntungkan dibanding instrumen investasi konvensional (Fintek, PT Amartha Mikro, 2017)\

\section{Crowd Funding}

Crowd funding adalah proses mengumpulkan dana untuk memulai suatu project atau bisnis yang sumber dananya berasal dari sejumlah besar orang (crowd) pengumpulannya memiliki batas waktu tertentu, misalnya 30-60 hari, dan prosesnya dilakukan melalui online platform. Pendanaan rakyat adalah sebuah inisiatif untuk mengumpulkan uang bagi sebuah proyek baru yang diusulkan oleh seseorang dengan mengumpulkan investasi berukuran kecil hingga menengah dari beberapa orang lainnya yakni orang banyak (Ordanini, 2011) 


\section{Digital Payment}

Definisi dari pembayaran elektronik sebagai "semua pembayaran yang diinisiasi, diproses dan diterima secara elektronik". Permintaan E-Payment telah muncul karena adanya toko online (Hartmann, 2006). Solusi pembayaran elektronik pertama, misalnya perbankan online sangat terinspirasi oleh transfer bank berbasis akun yang telah ditetapkan. Sejak saat itu ada solusi inovatif dan mudah untuk digunakan dan lebih sesuai dengan kebutuhan pedagang dan pelanggan (Dahlberg \& et-al, 2007). Proses pembayaran elektronik mencakup transfer sejumlah uang tertentu dari pembayar ke penerima pembayaran melalui mekanisme pembayaran elektronik independen-lokasi (Weir, 2006)

Berdasarkan informasi Databoks (2017) transaksi finansial teknologi (fintech) indonesia pada tahun 2017 diperkirakan mencapai US\$ 18,65 miliar. Angka ini akan melonjak menjadi US\$ 37,15 miliar pada tahun 2022, dengan Coumpound Annual Growth Rate (CAGR) 2017-2021 sebesar 18,8 \%. Besarnya populasi serta masih banyak penduduk Indonesia yang belum tersentuh lembaga keuangan merupakan tantangan bagi statrup fintech di tanah air. Dengan angka tersebut tentu saja tidak dapat dipungkiri lagi bahwa perusahaan fintech harus memiliki regulasi yang jelas dan tepat.

Dewan Syariah Nasional Majelis Ulama Indonesia menetapkan fatwa No: 117/DSN-MUI/II/2018 tentang Layanan Pembiayaan Berbasis Teknologi Informasi Berdasarkan Prinsip Syariah. Hal ini dilakukan karena layanan pembiayaan berbasis teknologi untuk pelaku usaha skala mikro, kecil dan menengah (UMKM) sebagai upaya memperoleh akses pendanaan lebih cepat, mudah dan efisien saat ini semakin berkembang melalui sarana fintech syariah. Masyarakat Indonesia memerlukan penjelasan mengenai ketentuan dan batasan hukum terkait layanan pembiayaan berbasis teknologi informasi berdasarkan prinsip syariah. Oleh karena itu, DSN-MUI menetapkan fatwa tentang layanan pembiayaan berbasis teknologi informasi berdasarkan prinsip syariah untuk dijadikan pedoman.

Terdapat dua lembaga keuangan yang ada di Indonesia yang terkait dengan sektor keuangan serta memiliki peran dalam menangani regulasi tersebut. Bank Indonesia (BI) dan Otoritas Jasa Keuangan (OJK) dalam hal ini memiliki peran penting dalam regulasi sektor keuangan di Indonesia dalam kegiatan yang dilakukan fintech terkait pembayaran dan pinjam meminjam. Oleh sebab itu, sistem pinjam meminjam (funding and landing) ditangani oleh OJK dan sistem pembayaran (payment system) ditangani oleh BI. Beberapa regulasi 
yang telah dikeluarkan oleh lembaga yang berwenang seperti Peraturan Otoritas Jasa Keuangan (POJK) Nomor 77/POJK.01/2016 tentang Layanan Pinjam Meminjam Uang Berbasis Teknologi Informasi (LPMUBTI).

Sedangkan Bank Indonesi (BI) mengeluarkan Regulation and Regulatory Sandbox pada kuartal ke empat tahun 2017 yakni PBI nomor 19/12/2017 tentang penyelenggaraan fintech, Peraturan Anggota Dewan Gubernur (PADG) nomor 19/14/PADG/2017 tehadap ruang uji coba (regulatory sandbox) dan PADG nomor 19/ 15/PADG/2017 tentang cara pendaftaran, peyampaian informasi dan pemantauan penyelenggaraan fintech. Program sandbox sendiri dipelopori Inggris untuk mendukung perkembangan fintech di negara tersebut. Program sandbox telah diadopsi oleh banyak negara seperti Hongkong, Australia, Singapore dan Malaysia. Program ini dapat menguji sistem dan bisnisnya dengan rentang waktu antara 6 bulan sampai 12 bulan sebelum bisnisnya dioperasikan secara penuh. Dalam masa uji coba tersebut, perusahaan fintech akan didampingi oleh pemerintah secara administrasi hukum dan operasional sistem, sehingga tidak ada aturan yang dilanggar oleh perusahaan fintech.

Kata "akad" (Arab = perikatan, perjanjian dan pemufakatan). Adapun menurut terminologi fiqih "akad" diartikan sebagai pertalian ijab, yaitu pernyataan melakukan ikatan dan qobul yang berarti pernyataan penerima ikatan yang sesuai dengan kehendak syari'at dan berpengaruh pada suatu perikatan. Sesuai dengan kehendak syari'ah seluruh perikatan yang dilakukan pihak-pihak terkait dianggap sah jika hal tersebut sejalan dengan syari'ah, sedangkan maksud dari berpengaruh pada suatu perikatan berarti terjadinya perpindahan kepemilikan dari satu pihak kepada pihak yang lain. (Zuhaili, 2010). Jika dilihat dari substansinya maka definisi akad ini menurut bahasa adalah Ar-rabbth (ikatan). Menurut pendapat Hanafiyah, akad adalah lahirnya suatu hak dan tanggung jawab terhadap suatu objek akad karena adanya ijab dan qobul. Sedangkan menurut pendapat Malikiyah, Syafi'iyah dan Hanabilah, definisi akad yaitu berakhirnya suatu hak, mengalihkan hak, melahirkan hak baik itu bersumber dari satu pihak ataupun dua pihak yang didasari oleh perilaku manusia.

Menurut Oni Sahroni (2016) yang dimaksud dengan akad yaitu "Pertalian atau keterikatan antara ijab dan qobul sesuai dengan kehendak syariah (Allah dan Rasul-Nya) yang menimbulkan akibat hukum dalam objek perikatan".

Kitab Undang-undang Hukum Perdata (KUH Perdata) pasal 1320 yang mengandung Asas kerelaan yang berisi bahwa "supaya terjadi perjanjian yang sah, perlu dipenuhi empat syarat kesepakatan mereka 
yang mengikatkan diri, kecakapan untuk membuat suatu perjanjian suatu pokok persoalan tertentu, suatu sebab yang tidak terlarang”.

\section{Fintech dan hubungannya dengan Maqhosid Syariah}

Transaksi yang sesuai dengan syariat Islam tentunya yang berlandaskan dari Al-Qur'an dan Hadits. Segala bentuk perekonomian dan transaksi bisnis menurut ajaran Islam yang bersumber dari AlQur'an dan Sunnah adalah untuk memperhatikan hak individu yang harus terlindungi sekaligus untuk menegakkan rasa solidaritas yang tinggi terhadap masyarakat (A, 2013).

Pada dasarnya akad yang terdapat dalam fintech tidak bertentangan selagi tidak melanggar prinsip syariah. Selain itu, fintech merujuk kepada salah satu asas muamalah yaitu an-taradhin yang memiliki arti saling ridho diantara keduanya. Asas inilah yang menjadi bagian terpenting atas sah nya suatu transaksi (Darsono dkk, 2016).

Menurut Aswad (2013) lembaga keuangan syariah yang mana harus mendasasi operasionalnya dengan prinsip syariah terhadap larangan atas riba, gharar dan maysir sehingga lebih menggiatkan kepada sistem bagi hasil (profit and lose sharing) sebagai penggantinya. Para pakar muslim sudah banyak yang menjelaskan bahwa landasan bunga (interest) sangat dilarang karena dapat menimbulkan terjadinya ketidakadilan (injustice) dalam tatanan ekonomi masyarakat. Sebaliknya, lembaga ekonomi syariah secara konsepsional didasarkan atas prinsip kemitraan berdasarkan kesetaraan (equity), keadilan (fairness), kejujuran (transparan), dan hanya mencari keuntungan yang halal semata (falah oriented).

\section{Pengertian Maqhasid Syariah}

Maqashid adalah bentuk plural dari maqashad, qasdh, maqashid atau qashud yang merupakan derivasi dari kata kerja (qashada yaqshidu) dengan beragam makna seperti menuju suatu arah, tujuan tengah-tengah adil dan tidak melampaui batas. Sementara itu, makna dari syari'ah secara etimologis merupakan jalan menuju mata air,alam terminology fiqh berarti hukum-hukum yang disyariatkan oleh Allah untuk hamba-Nya, baik yang ditetapkan melalui Al-qur'an maupun Sunnah Nabi Muhammad shallahu 'alaihi wa sallam yang berupa perkataan, perbuatan atau ketetapan Nabi. Adapun definisi secara singkat dan umum, yang dikutip dari buku karya Imam Mawardi dalam bukunya Fiqh Minoritas Fiqh Al- Aqaliyyat dan Evolusi Maqashid Al-Syari'ah dari Konsep ke Pendekatan, Al Rasyuni menyatakan bahwa syari'ah bermakna sejumlah hukum'amaliyyah 
yang dibawa oleh agama Islam, baik yang dibawa dalam konsepsi aqidah maupun hukumnya.

Adapun dari variasi definisi yang disebutkan oleh ulama klasik tersebut mengindikasikan bahwa terdapat kaitan erat maqashid alsyari'ah dengan hikmah, 'illat, tujuan atau niat dan kemaslahatan. Imam al Ghazali merupakan salah satu ulama klasik yang mendefinisikan bahwa "Maslahah adalah sebuah istilah yang pada intinya merupakan keadaan yang mendatangkan manfaat dan menolak bahaya atau kerugian. Yang kami maksudkan maqashid al-syari'ah sebenarnya bukan ini, karena mendatangkan manfaat dan menolak kerugian adalah tujuan dari makhluk. Kebaikan dari makhluk adalah menggapai tujuan-tujuannya. Yang kami maksudkan dengan maslahah disini adalah menjaga tujuan syara'. Tujuan syara' untuk maklhuk ada lima, yaitu menjaga agama, jiwa, akal, keturunan dan harta mereka".

Salah satu kajian istimewa mengenai maqashid al-syari'ah sebagaimana yang dikemukakan oleh al-Ghazali karena keberhasilannya menjabarkan aspe $k$ dharuriyyat menjadi aldharuriyyat al-khams, yang tanpanya maslahah dinyatakan tidak ada. Ia merupakan orang pertama yang memberikan nama al-dharuriyyat alkhams, menjelaskan secara memadai dan menyusunnya dengan urutan agama, jiwa, akal, keturunan dan harta sebagai hal-hal yang dilindungi oleh Islam. Kitabnya yang berjudul al-Mustasyfa fi 'ilm al-Ushul menjelaskan tentang hal ini. Penjelasannya yang lengkap mengenai konsep mashlahah dan prinsip-prinsip teoritis hukum Islam, al-Ghazali dikukuhkan dalam sejarah ushul al-figh sebagai peletak dasar ilmu ushul al-figh. Sementara itu al-Amidi merupakan orang pertama yang menguji susunan al-dharuriyyat al-khams tersebut dan mengambil "keturunan" sebelum "akal" seperti yang ditulis dalam al-Ihkam fi ushul alAhkam.

Selain menjaga agama, menjaga jiwa juga merupakan hal yang harus diterapkan dalam transaksi ekonomi. Hal itu berarti segala bentuk transaksi yang dapat menyakiti fisik dan psikis manusia harus dihindari demi keselamatan jiwa manusia. Apabila hal tersebut mendatangkan kemudharatan maka lebih baik ditinggalkan. Upaya demikian adalah sebagai bentuk tanggung jawab terhadap menjaga jiwa (hifdz an-nafs) yang dibebankan kepada setiap individu termasuk masyarakat.

Perintah menjaga jiwa telah Allah tuliskan didalam Al-Qur'an bisnis tersebut tidak dapat dipisahkan satu sama lain karena peran penting tersebut demi tercapainya kemaslahatan. Nilai agama yang terdapat dalam ekonomi yaitu dicerminkan dengan adanya halal dan haram yang harus diperhatikan. Misalnya, akad tijarah adalah muamalah yang halal, akad utang piutang dengan riba adalah muamalat 
yang haram. Akad yang pada dasarnya halal bisa menjadi haram apabila dalam transaksi tersebut terdapat keharama seperti, mengandung unsur-unsur penipuan, mengandung khamr, disini menetapkan yang terdapat dalam QS.Al-Quraisy:3-4). "Maka hendaklah mereka menyembah Tuhan pemilik rumah ini Ka'bah. Yang telah memberi makanan kepada mereka untuk menghilangkan lapar dan mengamankan mereka dari ketakutan".

Tujuan pemeliharaan yang selanjutnya yaitu menjaga keturunan. Maksud dari menjaga keturunan dalam hal ini yaitu menjaga generasi masa depan agar senantiasa berkesinambungan. Upaya menjaga keturunan tersebut antara lain sebagaimana terdapat dalam Hadits Rosulullah Shallalahu alaihi wa salam

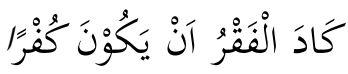

Hampir saja kemiskinan (kemiskinan jiwa dan hati) berubah menjadi kekufuran. (HR.Ath-Thabrani)

"Dan janganlah kamu serahkan kepada orang-orang yang belum sempurna akalnya, harta (mereka yang ada dalam kekuasaanmu) yang dijadikan Allah sebagai pokok kehidupan. Berilah mereka belanja dan pakaian (dari hasil harta itu) dan ucapkanlah kepada mereka kata-kata yang baik.” (QS.An-Nisa:5)

Orang dewasa yang tidak dapat mengatur harta bendanya termasuk dalam golongan orang yang belum sempurna akalnya sebagaimana orang yang belum baligh dan juga anak kecil. Sehingga mereka tidak dapat mengelola harta bendanya dengan baik. Dengan demikian, hukum mengatur semua itu dibingkai hifzh al-aql dalam ranah ekonomi syariah.

Menjaga harta merupakan kewajiban yang harus dilakukan oleh seseorang dalam mencapai maqasid syariah. Memiliki harta berupa mobil, rumah dan perabotan rumah merupakan hak manusia terhadap penjagaan terhadap harta. Sehingga dengan upaya menjaga harta tersebut terdapat banyak cara dalam mendapatkannya. Adapun cara yang didapatkan tersebut melalui cara halal ataupun haram. Harta dibagi dalam lima kategori sehingga menjadikan hukum atas benda tersebut. Adapun harta yang diperoleh dengan jalan yang halal serta dibelanjakan dijalan yang halal, maka harta tersebut harta yang baik. Kedua harta tersebut diperoleh dengan jalan yang haram lalu dibelanjakan dijalan yang haram juga maka itu termasuk seburukburuknya harta. Ketiga, harta tersebut diperoleh dengan jalan yang haram dan dibelanjakan pada jalan yang halal, maka harta tersebut termasuk dalam harta yang haram. Keempat, harta tersebut diperoleh 
dengan jalan yang halal namun dibelanjakan pada jalan yang haram, maka harta tersebut termasuk harta yang buruk. Kelima, harta tersebut diperoleh dengan cara yang mubah dan dibelanjakan pada jalan yang mubah pula, maka harta tersebut tidak tergolong dalam kategori baik atau buruk, namun dari transaksi tersebut tidak menguntungkan ataupun tidak menimbulkan dosa atasnya.

\section{Dinamika Fintech Syariah}

Kendala yang dihadapi oleh fintech syariah yakni mengenai perbedaan akad yang digunakan dalam suatu perusahaan fintech berbasis syariah, sistem kependudukan ganda yang dimiliki oleh pengguna sehingga menyusahkan pihak fintech syaiah dalam melakukan screening data calon peminjam dana, dan data center yang harus ada di Indonesia. Oleh sebab itu solusinya perlu adanya edukasi teknologi untuk masyarakat, peningkatan jaringan internet, percepatan menuju sistem kependudukan yang terintegrasi sehingga informasi yang didapatkan ketika kegiatan screening informasi calon peminjam adalah informasi yang valid (Adhi, 2018). Selain itu, kendala yang dihadapi oleh perusahaan fintech yakni syarat modal yang relatif tinggi ketika hendak mendaftar maka perusahaan yang akan mendaftar harus memiliki dana 1 Milyar dan ketika sudah terdaftar di OJK maka harus memiliki modal 2,5 Milyar. Sehingga hal tersebut menjadi kendala yang terjadi saat ini. Selain itu, jangkauan internet yang masih kurang dalam proses peningkatan kemajuan teknologi dalam bidang fintech. Serta kurangnya sosialisasi terhadap masyarakat yang ingin menggunakan teknologi fintech. Solusinya yakni dengan melakukan edukasi terhadap pelosok negeri sehingga seluruh lapisan masyarakat dapat menikmati kemudahan transaksi fintech, tanpa melewati pembekalan edukasi berdasarkan prinsip-prinsip syariah. Mengingat perkembangan fintech syariah sangat pesat maka sejak adanya gerakan 212 semua orang sedang melakukan eforia sehingga segala bentuk yang berbau syariah sedang ditunggu-tunggu oleh seluruh lapisan masyarakat. Namun semua hal tersebut tergantung kepada komitmen yang ada pada diri setiap individu dalam melakukan transaksi fintech syariah ini untuk menjadi unggul sehingga mampu bersaing dengan fintech konvensional. Tentu saja dengan tindakan menghindari dari riba menjadi keunggulan tersendiri bagi setiap individu yang ingin berhijrah dari ekonomi konvensional, sehingga ia sudah melakukan upaya untuk menghindarkan diri dari larangan yang Allah sebutkan dalam al-qur' an yakni ribawi. (Lubis, 2018)

Perlu adanya pembenahan dalam regulasi hukum karena peraturan yang saat ini dijadikan pedoman oleh fintech syariah masih 
mengikuti peraturan fintech konvensional. Sehingga belum terdapat peraturan khusus yang menjadi legalitas fintech syariah. Maka oleh sebab itu pihak regulasi harus membuat peratu khusus yang mengatut fintech syariah. Selain itu, dalam upaya mengembangkan fintech syariah bersama dengan anggota fintech lainnya sedang melakukan Edukasi Studi Fintech kepada seluruh lapisan masyarakat yang sesuai dengan prinsip-prinsip syariah (Arifin, 2018). Perlu adanya perhatian khusus dari perusahaan fintech supaya sesuai dengan maqashid syariahnya. Jangan sampai karna perkembangan fintech syariah, namun mengabaikan unsur-unsur syariahnya. Maka solusinya, dengan perkembangan fintech saat ini jangan sampai tertinggal zaman namun harus sesuai dengan prinsip syariah. Apabila dalam transaksi tersebut masih mengabaikan halal dan haramnya dalam suatu transaksi, niscaya keberkahan dalam rezeki yang dihasilkan tersebut akan dicabut oleh Allah Subhanahu wa ta'ala

\section{Kesimpulan}

Berdasarkan hasil pembahasan ini, dapat disimpulkan bahwa dengan menggunakan fintech yang berbasis syariah yang juga merupakan inovasi teknologi yang sesuai dengan ketentuan syariah serta menjadi solusi untuk dapat terhidar dari transaksi ribawi. Mengaplikasikan fintech syariah ini merupakan suatu tindakan bahwa kita sebagai umat Islam harus berpegang teguh kepada maqasid syariah. Menjaga agama, menjaga jiwa, menjaga keturunan, menjaga harta dan menjaga akal merupakan indikasi untuk meraih kemenangan dalam hidup (falah). Senantiasa mengharap ridho Allah Subhanahu wa ta'ala dalam segala aspek kehidupan yang dilakukan baik dalam bentuk ibadah yang bersifat hablu minallah (vertikal) maupun hablu minannaas muamalah (horizontal). Selain itu, dengan adanya fintech syariah ini juga sebagai upaya memudahkan setiap orang yang akan melakukan transaksi dan investasi berdasarkan prinsip syariah. Selain itu, terdapat beberapa poin penting yang menjadi kesimpulan dalam penelitian ini.

Pertama, pentingnya legalitas hukum yang mengatur secara khusus dalam masalah fintech syariah. Sehingga dengan peraturan tersebut semua lembaga fintech dapat berpedoman pada aturan yang telah dibuat secara resmi dalam mekanismenya. Kedua, dengan perluasan jangkauan internet yang menjadi faktor utama untuk mencapai kemudahan bagi semua lapisan masyarakat sehingga dapat dirasakan oleh setiap pengguna fintech. Ketiga, pengawasan fintech yang senantiasa menjadi tolak ukur akan tercapainya transaksi berdasarkan prinsip syariah yang terhindar dari maysir, gharar, riba. 
Keempat, keamanan yang ketat dalam menjaga identitas pengguna menjadi bagian yang sangat penting dalam fintech. Kelima, sosialisasi mengenai edukasi teknologi yang sesuai syariah menjadi upaya yang harus dilakukan oleh lembaga keuangan fintech syariah dalam menarik minat pengguna untuk bisa menikmati layanan fintech yang sesuai dengan prinsip Islam. Keenam, dengan adanya data screening yang menjadi fasilitas utama dalam mendeteksi kependudukan pengguna sehingga dapat membantu mempermudah akses pelayanan fintech.

Berdasarkan enam poin tersebut maka transaksi fintech akan sejalan dengan prinsip syariah. Sehingga dari keseluruhan akad yang terdapat dalam fintech syariah menjadi terarah dan sesuai dengan peraturan hukum positif dan juga hukum Islam. 


\section{Daftar Pustaka}

A, K. (2013). Hukum Bisnis Syariah dalam Al-Qur'an. Jakarta: AMZAH.

Adhi, W. T. (2018, Oktober 05). Kendala dan Solusi Fintech Syari'ah di Indonesia. (S. Nurhalimah, Interviewer)

Arifin, A. (2018, Agustus 4). Kendala dan Solusi Fintech Syariah di Indonesia. (S. Nurhalimah, Interviewer)

Arner, D. W. (2016). Opportunities and Challenges. Fintech and RegTech.

Dahlberg, T., \& et-al. (2007). Past, present and future of mobile payments research A literature review. (T. e.-a. Dalhberg, J. Ondrus, \& A. Zmijewska, Eds.) Electronic Commerce Research and Applications, 1-17.

Fintek, PT Amartha Mikro. (2017). Dipetik Oktober 1, 2018, dari https://amartha.com

Hartmann, M. E. (2006). Handbuch E-Money, E-Payment \& MPayment. (L. (Ed.)Th., Ed.) A product of physica Verlag Heidelberg.

Kasali, R. (2017). Discruption. Jakarta: Gramedia Pustaka Utama.

Lubis, Z. (2018, Agustus 08). Kendala dan Solusi Kesesuaian Fintech Syariah di Indonesia. (S. Nurhalimah, Interviewer)

Ordanini, A. d. (2011). Crowd-funding transforming customers into investors through innovative service platforms. (A. d. Ordanini, Penyunt.) Journal of Service Management, 22(4), pp443-470.

Prasetyoningsih, N. (2014). Jurnal Media Hukum. Dampak Pemilihan Umum Serentak Bagi Pembangunan Demokrasi Indonesia.

Shidik, S. (2016). Ushul Fiqh. Jakarta: PT INTIMEDIA CIPTA NUSANTARA.

Weir, C. S. (2006). On the role of metaphore and languange in design of third party payments in eBanking: Usability and quality. International journal of Human-Computer Studies, Vol. 64 Issue $8770-784$.

Zuhaili, W. a. (2010). Fiqh Islam Wa Adillatuhu 1. Jakarta: Gema Insani. 
